\title{
GIP as a Potential Therapeutic Target for Atherosclerotic Cardiovascular Disease-A Systematic Review
}

\author{
Yusaku Mori $^{1, *(\mathbb{D}}$, Takanori Matsui ${ }^{2}\left(\mathbb{D}\right.$, Tsutomu Hirano $^{1,3}$ and Sho-ichi Yamagishi ${ }^{1}$ \\ 1 Division of Diabetes, Metabolism, and Endocrinology, Department of Medicine, \\ Showa University School of Medicine, Shinagawa, 142-8555 Tokyo, Japan; \\ hirano@med.showa-u.ac.jp (T.H.); shoichi@med.showa-u.ac.jp (S.-i.Y.) \\ 2 Department of Pathophysiology and Therapeutics of Diabetic Vascular Complications, Kurume University \\ School of Medicine, Kurume, 830-0011 Fukuoka, Japan; matsui_takanori@med.kurume-u.ac.jp \\ 3 Diabetes Center, Ebina General Hospital, Ebina, 243-0433 Kanagawa, Japan \\ * Correspondence: u-mori@med.showa-u.ac.jp; Tel.: +81-3-3784-8947
}

Received: 12 February 2020; Accepted: 21 February 2020; Published: 22 February 2020

check for updates

\begin{abstract}
Glucose-dependent insulinotropic polypeptide (GIP) and glucagon-like peptide-1 (GLP-1) are gut hormones that are secreted from enteroendocrine $\mathrm{L}$ cells and $\mathrm{K}$ cells in response to digested nutrients, respectively. They are also referred to incretin for their ability to stimulate insulin secretion from pancreatic beta cells in a glucose-dependent manner. Furthermore, GLP-1 exerts anorexic effects via its actions in the central nervous system. Since native incretin is rapidly inactivated by dipeptidyl peptidase-4 (DPP-4), DPP-resistant GLP-1 receptor agonists (GLP-1RAs), and DPP-4 inhibitors are currently used for the treatment of type 2 diabetes as incretin-based therapy. These new-class agents have superiority to classical oral hypoglycemic agents such as sulfonylureas because of their low risks for hypoglycemia and body weight gain. In addition, a number of preclinical studies have shown the cardioprotective properties of incretin-based therapy, whose findings are further supported by several randomized clinical trials. Indeed, GLP-1RA has been significantly shown to reduce the risk of cardiovascular and renal events in patients with type 2 diabetes. However, the role of GIP in cardiovascular disease remains to be elucidated. Recently, pharmacological doses of GIP receptor agonists (GIPRAs) have been found to exert anti-obesity effects in animal models. These observations suggest that combination therapy of GLP-1R and GIPR may induce superior metabolic and anti-diabetic effects compared with each agonist individually. Clinical trials with GLP-1R/GIPR dual agonists are ongoing in diabetic patients. Therefore, in this review, we summarize the cardiovascular effects of GIP and GIPRAs in cell culture systems, animal models, and humans.
\end{abstract}

Keywords: animal model; atherosclerosis; cardiac remodeling; GIP; restenosis

\section{Introduction}

Atherosclerotic cardiovascular disease (CVD) is a major cause of death and disability among individuals with diabetes in many countries [1,2]. Indeed, a hazard ratio among individuals with diabetes as compared with those without diabetes was 1.8 for death from CVD even after adjusting for several well-known risk factors such as high systolic blood pressure and serum cholesterol levels [1]. However, the effects of strict blood glucose control on CVD are marginal, especially in diabetic patients with a long disease history [3-7]. These observations suggest that development of novel therapeutic strategies is needed to further reduce the risk of CVD and subsequently improve the quality of life in both type 1 and type 2 diabetic patients [1,8-10]. 
Glucose-dependent insulinotropic polypeptide (GIP) and glucagon-like peptide-1 (GLP-1) are gut hormones that are secreted from enteroendocrine $\mathrm{L}$ cells and $\mathrm{K}$ cells, respectively, in response to stimuli with digested nutrients [11,12]. GIP and GLP-1 are also referred to as incretins for their ability to stimulate insulin secretion from pancreatic beta cells in a glucose-dependent manner. Furthermore, GLP-1 exerts anorexic effects through its actions on the central nervous system [11,12]. Since native incretin is rapidly inactivated by dipeptidyl peptidase-4 (DPP-4), DPP-resistant GLP-1 receptor agonists (GLP-1RAs) and DPP-4 inhibitors have been developed and now widely used for the treatment of diabetic patients as incretin-based agents because of their superiority to classical insulinotropic agents, such as sulfonylureas and glinides from the standpoint of low risks for hypoglycemia and body weight gain [13-15].

Both GIP and GLP-1 have been reported to exert direct effects on the cardiovascular system in addition to pancreatic beta cells $[12,16]$. Indeed, a number of preclinical studies, including ours, have shown the cardiovascular protective effects of native incretins and incretin-based agents partly in a glucose-lowering independent manner [17-28], whose observations were consistent with the recent cardiovascular outcome trials demonstrating that GLP-1RAs significantly reduced the cardiovascular and renal events in high-risk type 2 diabetic patients compared with placebo [29-33]. Furthermore, DPP-4 inhibitors have also been shown to improve surrogate markers of atherosclerotic CVD in several clinical trials [34-36], although their effects on CV hard events were neutral in various cardiovascular outcome trials [37-41]. Based on these clinical findings, GLP-1RAs have now recommended as one of the first-line therapies in metformin-treated type 2 diabetic patients with high risks or established CVD.

In contrast to the case of GLP-1, no GIP receptor (GIPR) agonist is clinically utilized to date because its therapeutic potential was doubted by the observations showing impaired insulinotropic effects of GIP in individuals with diabetes [42-44]. In addition, inhibition of physiological GIP has been shown to prevent the body weight gain in high-fat diet (HFD) fed mice by suppressing the GIP-induced adipogenesis in adipose tissues [45-48], thereby raising safety concerns that GIP treatment could promote obesity and deteriorate the metabolic risks in type 2 diabetic patients. Therefore, cardiovascular effects of GIP had been almost neglected. However, paradigm of GIP-based therapy has been changed by recent preclinical studies, which showed that administration of GIP analogs at pharmacological doses or overexpression of GIP could suppress the HFD-induced body weight gain as is the case of the inhibition of physiological GIP, probably through the anorexic effects of GIP on the central nervous system [49-53]. These observations were further supported by a recent clinical trial, which showed that LY3298176, a dual agonist targeting for GIPR and GLP-1R exerted superior effects on glycemic controls and body weight reductions compared with GLP-1RA, dulaglutide monotherapy in patients with type 2 diabetes [54]. Given the fact that clinical trials with dual (GLP-1R/GIPR) or triple (GLP-1R/GIPR/glucagon receptor) agonists are ongoing in diabetic patients $[55,56]$, attention will be paid whether combination therapy with incretin-based therapy, such as GIPR agonists and GLP-1RAs, could be more effective for preventing the CVD than GLP-1RA monotherapy in type 2 diabetic patients. However, to data, there is no clinical trial to address the issue. Therefore, this article summarizes the cardiovascular effects of GIP and GIPRAs in cell culture systems, animal models, and humans. Although several observational studies reported the correlation between circulating GIP levels and presence or severity of atherosclerotic CVDs, these data are not included in this review because we cannot draw a definite conclusion from observational studies whether GIP acts as a causal or compensative protective factor for CVD. In this review, literature searches were undertaken in Medline by the PubMed interface. Non-English language articles were excluded. Key words (GIP [glucose-dependent insulinotropic polypeptide, glucose-dependent insulinotropic peptide, or gastric inhibitory polypeptide] and (atherosclerosis, restenosis, heart, artery, inflammation, adipose tissue, endothelial cell, smooth muscle cell, monocyte, macrophage, adipocyte, and desensitization) have been used to select the articles. 


\section{Cell Culture Studies}

\subsection{Vascular Endothelial Cells (VECs)}

VEC plays a central role in the maintenance of cardiovascular homeostasis mainly via nitric oxide (NO) production [57], and their dysfunction is involved in the pathogenesis of early phase of atherosclerosis [58]. GIPR has also shown to be expressed in various types of VECs [27,59-63]. GIPR belongs to the glucagon receptor subfamily of $G$ protein-coupled receptor class $B$, and its signaling is mainly mediated by cyclic adenosine monophosphate (cAMP) pathway in pancreatic beta cells [11,12]. However, GIPR signaling pathway in VECs is possibly distinct from that in pancreatic beta cells, whereas effects of GIP may differ among VEC types $[60,64-66]$. There is an in vitro study showing the different effects of GIP on VECs isolated from hepatic artery and portal vein of canine [64]. GIP stimulated cell proliferation in either type of VECs without affecting intracellular cAMP levels. However, ranging from 0.1 to $10 \mathrm{nM}$, GIP dose-dependently increased the intracellular calcium levels and NO production without affecting endothelin-1 production in ECs of portal vein. On the other hand, GIP did not affect the intracellular calcium levels or NO production, but increased endothelin-1 production in ECs of hepatic artery. These observations are consistent with in vivo findings that GIP infusion dose-dependently increased portal vein blood flow but decreased hepatic artery blood flow in conscious dogs [65]. The subsequent study by the same group showed that immortalized ECV 304 cells and ECs collected from human umbilical vein (HUV), aorta, and pulmonary artery contained different splicing patterns of GIPR [66]. Indeed, responses to GIP stimulation, as assessed with elevations in intracellular calcium levels, were different among these VECs, and GIP-induced activation of cAMP-dependent protein kinase, also known as protein kinase a (PKA), was observed only in HUVEC. These observations were further supported by a study that ranging from 0.1 to $100 \mathrm{nM}$, GIP concentration-dependently increased the endothelin-1 (ET-1) production in HUVECs, but not ECV 304 cells [60]. Although it remains unclear why effects of GIP are varied between VEC types, a couple of studies suggested the involvement of GIPR splicing variants in GIP actions [67,68]. The truncated GIPR retaining intron 8 was co-expressed with functional GIPR in pancreatic beta cells of mice, and the induction of truncated GIPR gene impaired the GIP-induced cAMP production in cells expressing functional GIPR [67]. Furthermore, 64 possible variants of GIPR were detected in human adipose tissues, and only two of them contained the functional domain [68]. However, further studies are needed to clarify whether GIPR splicing variants can be involved in altered GIP actions between VEC types.

Anti-atherogenic effects of GIP on VECs were reported by several studies using HUVECs (Table 1) $[27,61,63]$. Accumulation of advanced glycation end products (AGEs) is a causal factor for atherosclerosis through dysfunction, inflammation, apoptosis, and other various adverse responses of VECs [69,70]. We have previously found that active GIP at $50 \mathrm{pM}$ inhibited the generation of reactive oxygen species via reductions in gene expression levels of receptor for AGEs in AGEs-exposed HUVECs, with concomitant reductions in gene expression levels of pro-atherogenic molecules, such as vascular cell adhesion molecule and plasminogen activator inhibitor-1 (Pai-1) [61]. GIP at $1 \mathrm{nM}$ also increased the production of NO, the potent anti-atherogenic molecule [57] through the activation of endothelial nitric oxide synthase (NOS) in HUVECs, whereas it decreased inflammatory inducible NOS expression levels [63]. Furthermore, we have found that active, but not inactive GIP at $1000 \mathrm{nM}$ increased the NO production via the activation of AMP-activated protein kinase (AMPK) in HUVECs [27], while GIP-induced AMPK activation was mediated by phospholipase C (PLC) and calcium/calmodulin-dependent protein kinase kinase (CaMKK), but not adenyl cyclase or liver kinase B1 (LKB1). These findings suggest the possible involvement of GIPR/PLC/CaMKK/AMPK/NO axis in the anti-atherogenic effects of GIP [71-73]. However, a couple of studies reported the pro-atherogenic effects of GIP on VECs (Table 1) [60,62,64]. As above-mentioned, GIP increased the production of ET-1 [60,64], which acts as a pro-atherogenic molecule [74]. Another study showed that GIP evoked the ET-1 production in aortic ECs of mice via cAMP response element-binding protein (CREB)-dependent, 
but cAMP/PKA-independent mechanisms [62]. In addition, EC-produced ET-1 subsequently stimulated the pro-atherogenic osteopontin production in aortic smooth muscle cells (SMCs) [62,75]. In consistent with the observations, GIP-induced elevations in ET-1 and osteopontin protein productions were observed in isolated mouse aorta ex vivo [62]. However, it remains unclear whether the inhibition of physiological levels of GIP can result in the suppression of atherosclerosis in vivo. Taken together, GIP could exert both anti-atherogenic and pro-atherogenic effects, which may depend on VEC types.

Table 1. Effects of glucose-dependent insulinotropic polypeptide (GIP) on cultured cells related to cardiovascular disease. $\uparrow$, increase; $\rightarrow$, no change; $\downarrow$ decrease.

\begin{tabular}{|c|c|c|c|}
\hline Cell Type & & Anti-atherogenic & Pro-atherogenic \\
\hline \multirow[t]{7}{*}{ VEC } & Canine portal vein EC & $\uparrow \mathrm{NO}$ production [64] & \\
\hline & Canine hepatic artery EC & & $\uparrow$ ET-1 level [64] \\
\hline & & $\begin{array}{c}\downarrow \text { AGEs-induced oxidative stress } \\
\text { and inflammation [61] }\end{array}$ & \\
\hline & HUVEC & $\uparrow$ NO production $[27,63]$ & $\uparrow$ ET-1 level [60] \\
\hline & & $\uparrow$ AMPK activation [27] & \\
\hline & & $\downarrow$ iNOS level [63] & \\
\hline & Mouse aortic EC & & $\uparrow$ ET-1 level [62] \\
\hline \multirow[t]{2}{*}{ VSMC } & Human aortic SMC & $\begin{array}{l}\downarrow \text { Growth factor-induced cell } \\
\text { proliferation [20] }\end{array}$ & \\
\hline & Mouse aortic SMC & & $\rightarrow$ Osteopontin level [62] \\
\hline \multirow[t]{2}{*}{$\begin{array}{c}\text { Monocyte } \\
\text { /macrophage }\end{array}$} & Human THP-1 cell & $\begin{array}{c}\downarrow \text { Inflammation [76] } \\
\downarrow \text { Migration [77] }\end{array}$ & \\
\hline & Mouse RAW 264 cell & $\begin{array}{c}\downarrow \text { Inflammation [77] } \\
\downarrow \text { Migration [77] }\end{array}$ & $\uparrow$ Inflammation [78] \\
\hline \multirow[t]{3}{*}{ Adipocyte } & $\begin{array}{l}\text { Isolated human } \\
\text { adipocyte }\end{array}$ & $\begin{array}{l}\text { 个 Adiponectin level [79] } \\
\text { Inflammation [80] }\end{array}$ & \\
\hline & Isolated rat adipocyte & $\uparrow$ Adiponectin level [79] & $\begin{array}{c}\uparrow \text { Inflammation [81] } \\
\uparrow \text { Osteopontin level } \\
{[82,83]}\end{array}$ \\
\hline & Mouse 3T3-L1 cell & & $\begin{array}{c}\uparrow \text { Inflammation }[82,84] \\
\uparrow \text { Osteopontin level [83] } \\
\rightarrow \text { Inflammation [78] } \\
\downarrow \text { Adiponectin level }[84]\end{array}$ \\
\hline
\end{tabular}

\subsection{Vascular Smooth Muscle Cells (VSMCs)}

VSMCs exist in the media of vasculatures as contractile form under physiological conditions. Growth factors, some of which can be produced from atherosclerotic plaque, induce a phenotypic switch from contractile to synthetic form, which are prone to proliferation, migration and extracellular matrix production, thereby contributing to the progression of atherosclerosis [85]. GIPR protein was barely detected in the media of mouse aorta [62]. However, gene expression levels of Gipr in cultured mouse aortic SMCs were upregulated by stimulation with growth factors, thus suggesting that GIP may act on synthetic, but not contractile form of VSMCs [62]. Indeed, we have found that active GIP suppressed the growth-factor-stimulated cell proliferation in human aortic SMCs (Table 1) [19]. On the other hand, GIP did not directly affect osteopontin production, which was indirectly evoked by GIP-induced production of ET-1 from VECs [62]. However, the underlying mechanisms and other biological effects of GIP on VSMCs remain to be elucidated.

\subsection{Monocytes, Macrophages, and Adipocytes}

The cascade of monocyte attachment and infiltration to vessel walls, differentiation to macrophages, and form cell formation contribute to the pathogenesis of atherosclerosis [85-91]. In addition, adipose tissue inflammation also plays a role in the promotion of atherosclerosis through the altered production of inflammatory cytokines/chemokines and adipokines [92]. We have previously found that GIPR is expressed in monocytes, but its level is considerably downregulated after differentiation to macrophages, thereby indicating the involvement of GIP in the inflammatory responses [19]. 
Indeed, a couple of studies showed the anti-inflammatory effects of GIP in immune cells (Table 1) [76,77]. GIP ranging from 1 to $100 \mathrm{nM}$ dose-dependently suppressed the lipopolysaccharide (LPS)-induced gene expression levels of tumor necrosis factor (TNF) or inducible NOS in human monocyte THP-1 cells, and these effects were abolished by inhibiting adenyl cyclase or PKA, but not exchange protein directly activated by cAMP 2 [76]. This suggests the involvement of GIPR/adenyl cyclase/PKA axis. The anti-inflammatory effects of GIP on monocytes were further demonstrated by a recent study showing that active GIP suppressed the chemokine ligand 2 (CCL2)-induced migration of mouse monocyte RAW 264 cells and human monocyte THP-1 cells thorough reductions in gene expression levels of chemokine receptor type 2 [77]. In addition, active GIP also inhibited the matrix metalloproteinase-9 protein levels and interleukin (IL)-6 production by suppressing LPS-induced activation of nuclear factor-kappa B p65 and mitogen-activated protein kinases in mouse monocyte RAW 264 cells [77].

GIPR has also been shown to be expressed abundantly in differentiated, but not undifferentiated premature adipocytes $[82,93,94]$, and its expression levels were also upregulated by various stimuli, such as IL-1 $\beta$ or hypoxia-inducible factor- $1 \alpha$ activator, and exposure to hypoxic conditions [82]. Anti-inflammatory effects of GIP on adipocytes are reported by several studies (Table 1) [79,80]. GIP at $100 \mathrm{nM}$ increased the gene expression levels of Adiponectin in isolated rat and human adipocytes [79]. Furthermore, DPP4-resistant [D-Ala2] GIP at $100 \mathrm{nM}$ in the presence of insulin reduced the gene expression levels of IL-1 beta, IL-6, CCL8, and progranulin in adipocytes collected from mesenteric adipose tissue of obese individuals [80]. However, pro-inflammatory effects of GIP on adipocytes are also reported by several studies (Table 1) [68,78,81-84]. In differentiated mouse 3T3-L1 adipocytes overexpressing GIPR, GIP increased the gene expression levels of Il-6, Tnf-alpha, Ccl2 and Ccl7, but decreased those of adiponectin and leptin, which were mediated by IKK $\beta$ or PKA, and partially by c-Jun-NH2-terminal kinase [84]. In addition, subsequent studies reported that GIP at 1 or $100 \mathrm{nM}$ also increased the protein levels of IL6 and IL-1 receptor antagonist in the presence of LPS, IL-1 $\beta$, or TNF- $\alpha$ in adipocytes obtained from subcutaneous abdominal fat pads of non-obese and obese individuals [81], and that GIP at $10 \mathrm{nM}$ increased the production of IL6 and CCL2 in differentiated mouse 3T3-L1 adipocytes [82]. Another study reported that GIP at $100 \mathrm{nM}$ increased the gene expression levels of $\mathrm{Ccl} 2$ in mouse monocyte RAW 264 cells, but not differentiated mouse 3T3-L1 adipocytes [78]. GIP at 1 to $100 \mathrm{nM}$ also increased the protein levels of osteopontin in insulin-treated mouse 3T3-L1 adipocytes and isolated rat adipocytes via the transcription factor nuclear factor of activated T-cells [83], which was further confirmed in cultured rat visceral adipocytes under normal and high glucose conditions [68]. Collectively, GIP is likely to exert anti-inflammatory effects on monocytes, whereas its effects on adipocyte inflammation are controversial.

\section{Animal Studies}

\subsection{Atherosclerosis Models}

Atherosclerosis is the main cause of tissue ischemia and infarction in brains and hearts, and its prevention has long been a potential therapeutic target to suppress the CVD in individuals with diabetes $[1,2]$. Anti-atherogenic effects of GIP in mouse models were reported by several research groups (Table 2) $[19,21,77]$. We have found in atherosclerosis-prone apolipoprotein $E$ knockout (ApoE-/-) mice [95] that chronic infusion of active GIP (25 nmol/ $\mathrm{kg} /$ day) for 4 weeks suppresses the aortic plaque formation and intra-plaque macrophage accumulation compared with vehicle treatment, whose effects were totally independent of food intake, body weight, systolic blood pressure, and plasma glucose and lipid levels [19]. In our study, inactive GIP infusion showed no effects on atherosclerosis. Furthermore, active GIP, but not inactive GIP infusion, suppressed the macrophage foam cell formation in ex vivo experiments, which plays a crucial role in the development and progression of atherosclerosis [90,91], whereas it decreased protein expression levels of CD36 and acetyl-coenzyme a acetyltransferase-1, which are involved in oxidized low density lipoprotein (LDL) 
uptake and intracellular cholesterol storage, respectively. We have also observed the anti-atherogenic effects of GIP in diabetic animals [21]. The infusion of active GIP ( $25 \mathrm{nmol} / \mathrm{kg} /$ day) for 4 weeks reduced the aortic plaque formation, intra-plaque macrophage accumulation, macrophage foam cell formation in streptozotocin-induced diabetic ApoE-/- mice. In addition, recently, overexpression of GIP has been reported to stabilize the atherosclerotic plaque in non-diabetic ApoE--- mice [77]; overexpression of GIP gene reduced macrophage accumulation and increased collagen content of aortic plaques, while it did not induce body weight gain. Taken together, these findings suggest that GIP at pharmacological concentrations could exert protective effects against atherosclerosis without deteriorating the obesity, and the beneficial effects of GIP might also be preserved in diabetic animals. However, it remains unclear whether GIP infusion at the physiological dose suppresses or promotes atherosclerosis in animal models.

\subsection{Restenosis Models}

Percutaneous transluminal angioplasty (PTA) and bypass graft are common revascularization procedures for the treatment of atherosclerotic vascular disease that could cause the ischemia or infarction of hearts $[96,97]$. PTA in combination with drug-eluting stents can be widely applicable to coronary heart disease patients with various comorbidity due to its less invasiveness than bypass graft. However, its long-term coronary artery patency is still limited by substantial rate of restenosis, especially in high-risk patients, such as diabetic subjects [96,97]. One of the main causes of restenosis is neointimal hyperplasia, which chronically occurs at the site of the intervention as an exaggerated healing response to vascular injury caused by PTA procedures [98]. We have previously investigated the effects of pharmacological and physiological doses of GIP on restenosis using mouse models of femoral artery wire injury (Table 2) [27]. The infusion of active GIP (50 nmol/ $\mathrm{kg} /$ day), but not inactive GIP for 4 weeks suppressed the injury-induced neointimal hyperplasia and vascular cell proliferation without affecting the metabolic parameters, including body weight gain. In addition, active GIP infusion also facilitated the regeneration of VECs, which were completely denuded after wire insertion [27]. Furthermore, the active GIP infusion also significantly reduced the injury-induced neointimal hyperplasia and vascular cell proliferation in diabetic $d b / d b$ mice, an animal model of type 2 diabetes with obesity as well [27]. Interestingly, co-treatment with a NOS inhibitor, nitro-L-arginine methyl ester completely abolished the beneficial effects of active GIP, thus suggesting the involvement of NO-dependent mechanisms in atheroprotective actions of GIP [27]. In contrast, whole-body deletion of GIPR gene in wild-type mice promoted the neointimal hyperplasia after vascular injury [27]. Therefore, pharmacological GIP may be beneficial to inhibit the restenosis after PTA through the suppression of neointimal hyperplasia both in non-diabetic and diabetic animals. 
Table 2. Cardiovascular effects of GIP in animal models of cardiovascular disease. $\uparrow$, increase; $\rightarrow$, no change; $\downarrow$ decrease.

\begin{tabular}{|c|c|c|c|}
\hline Animal Model & & GIPR Activation & GIPR Inhibition \\
\hline Atherosclerosis & $\begin{array}{c}\text { ApoE knockout } \\
\text { (male C57BL/6-background mice) } \\
\text { ApoE knockout with diabetes } \\
\text { (male C57BL/6-background mice) }\end{array}$ & $\begin{array}{c}\downarrow \text { Plaque formation [19] } \\
\downarrow \text { Macrophage foam cell formation } \\
{[19]} \\
\uparrow \text { Plaque stability [77] } \\
\downarrow \text { Plaque formation [20] } \\
\downarrow \text { Macrophage foam cell formation } \\
{[20]}\end{array}$ & \\
\hline Restenosis & $\begin{array}{c}\text { Femoral artery wire injury } \\
\text { (male C57BL/6 mice) } \\
\text { Femoral artery wire injury with } \\
\text { diabetes (male } d b / d b \text { mice) }\end{array}$ & $\begin{array}{c}\downarrow \text { Neointimal formation [27] } \\
\uparrow \text { endothelial regeneration [27] } \\
\downarrow \text { Neointimal formation [27] }\end{array}$ & $\begin{array}{c}\uparrow \text { Neointimal formation } \\
{[27]}\end{array}$ \\
\hline Cardiac remodeling & $\begin{array}{c}\text { Angiotensin II infusion (male } \\
\text { C57BL/6-background ApoE } \\
\text { knockout mice) } \\
\text { Coronary artery ligation (male } \\
\text { C57BL/6-background mice) } \\
\text { Transverse aortic constriction } \\
\text { (male C57BL/6-background mice) } \\
\text { Doxorubicin injection (male } \\
\text { C57BL/6-background mice) }\end{array}$ & $\begin{array}{c}\downarrow \text { Cardiomyocyte enlargement [25] } \\
\downarrow \text { interstitial fibrosis [25] } \\
\uparrow \text { Scar formation [99] }\end{array}$ & 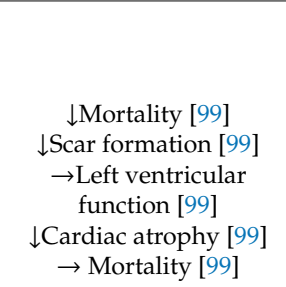 \\
\hline Inflammation & $\begin{array}{c}\text { Standard diet } \\
\text { (Ref. 49: male C57BL/6 mice, Ref. } \\
\text { 86: male } d b \text { mysty mice) } \\
\text { High fat diet } \\
\text { (Ref. 50: C57BL/6-background } \\
\text { mice [no information for sex], Ref. } \\
\text { 89: male F344/jcl rats, Ref. 90: } \\
\text { male C57BL/6 mice, Ref. 109: no } \\
\text { information for background strain } \\
\text { and sex) } \\
\text { Diabetes } \\
\text { (male } d b / d b \text { mice) } \\
\text { Gingivitis } \\
\text { (male C57BL/6-background mice) } \\
\text { Endotoxemia } \\
\text { (male C57BL/6 mice) }\end{array}$ & $\begin{array}{c}\downarrow \text { Adipose tissue inflammation [49] } \\
\uparrow \text { Adipose tissue inflammation [82] } \\
\begin{array}{c}\downarrow \text { Adipose tissue inflammation } \\
{[50,79,80]}\end{array} \\
\uparrow \text { Adipose tissue expression and } \\
\text { blood levels of adiponectin }[79,80]\end{array}$ & $\begin{array}{c}\uparrow \text { Gingival inflammation } \\
{[76]}\end{array}$ \\
\hline
\end{tabular}

\subsection{Cardiac Remodeling Models}

Heart failure has become one of the major causes of $\mathrm{CV}$ death in individuals with diabetes, who are at high risk for heart failure and death $[102,103]$. The pathology of heart failure in diabetes is associated with cardiac remodeling caused by complexes of atherosclerotic coronary disease and diabetic cardiomyopathy, resulting in systolic and diastolic dysfunction [104-106]. However, effective therapy to ameliorate cardiac remodeling in diabetes is still limited. GIPR has been shown to be expressed both in the atrium and ventricle of mice and human hearts, thus suggesting that the heart is one of the extra-pancreatic target organs for GIP $[25,59,99]$. We have previously found that GIP plays a protective role against cardiac remodeling in ApoE-/- mice infused with angiotensin II (Table 2) [25], whose pathway is also activated in diabetic cardiomyopathy [104-106]. Indeed, infusion of active GIP ( $25 \mathrm{nmol} / \mathrm{kg} /$ day) for 4 weeks suppressed the left ventricle cardiomyocyte enlargement and interstitial fibrosis, which were associated with concomitant reductions in cell apoptosis and transforming growth factor- $\beta$ protein expression in the hearts of angiotensin II-infused ApoE-/- mice [25]. In other studies, effects of GLP-1 on infarcted rat hearts were evaluated [99,107-109]. In the infarcted rat hearts induced by coronary artery ligation, perfusion with GIP, but not GLP-1 at the infusion rate at $100 \mathrm{nmol} / \mathrm{l}$ for $1 \mathrm{~h}$ reduced the protein expression levels of resistin [107], a promoter of cardiac remodeling and dysfunction $[108,109]$. In contrast to the findings, deleterious effects of GIP on cardiac remodeling were also reported in mouse models of myocardial infarction (Table 2) [99]. GIPR gene expression levels in the heart were upregulated at one day but recovered to the baseline at two days after the induction of myocardial infarction. One-week pre-treatment with [D-Ala2] GIP injections ( $24 \mathrm{nmol} / \mathrm{kg}$ body weight, twice daily), did not affect the mortality, but increased the left ventricle scar formation 
at two weeks after the induction of myocardial infarction in wild-type mice. On the other hand, both whole-body and cardiomyocyte-specific deletion of GIPR gene reduced the infarction-induced mortality, ventricular weight, and left ventricle scar formation [99]. Interestingly, whole-body deletion of GIPR gene did not affect the survival or left ventricle function in doxorubicin-induced or transverse aortic-constriction-induced heart failure mice [99]. Collectively, these findings suggest that effects of GIP on cardiac remodeling may differ depending on experimental conditions. Administration of GIP at the pharmacological dose may prevent the angiotensin II-induced cardiac hypertrophy, while inhibition of physiological levels of GIP could suppress the cardiac remodeling after myocardial infarction.

\subsection{Inflammation Models}

Inflammation plays a crucial role in the development and progression of atherosclerotic CVD [85-89]. Several studies have shown the anti-inflammatory properties of GIP (Table 2) [49,50,79,80]. The injections of [D-Ala2] GIP $(0.12 \mathrm{mg} / \mathrm{kg}$ body weight, once daily) decreased the adipose tissue gene expression levels of pro-inflammatory cytokines, such as Il-1beta, Il-6, Tnf-alpha in wild-type mice fed with standard diet [49]. Moreover, overexpression of GIP gene attenuated the gene expression levels of pro-inflammatory molecules, including Ccl2, inhibitor of nuclear factor kappa-B kinase subunit beta, Il-4 receptor alpha, Tnf receptor superfamily member $1 b$, and Pai-1 in the epididymal fats of HFD-fed mice [50]. Consistent with the case of GIP overexpression, administration of GIP $(10 \mu \mathrm{g} / \mathrm{kg}$, twice daily) for 2 weeks increased the blood levels of adiponectin, an anti-inflammatory and insulin-sensitizing adipokine in HFD-fed rats, which were accompanied with its increased gene expression and decreased Tnf-alpha and Pai-1 gene in the stromal vascular fraction of epididymal fat [79]. In addition, once daily injections of [D-Ala2] GIP $(0.12 \mu \mathrm{g} / \mathrm{g})$ decreased the infiltration of inflammatory immune cells into, and gene expression levels of Tnf-alpha, Il-1beta, interferon- $\gamma$, fractalkine, Ccl2, Ccl5, and Ccl8 in, the epididymal fat of HFD-fed mice, which were accompanied with reductions in the number of circulating bone marrow-derived monocytes and neutrophils [80]. On the other hand, the [D-Ala2] GIP injections increased the epididymal gene expression and blood levels of adiponectin [80]. The anti-inflammatory effects of GIP have also been observed in other tissues [76,101]. Whole-body deletion of GIPR gene promoted the gingival macrophage infiltration and gene expression levels of Tnf-alpha and inducible nos in a mouse model of periodontitis [76]. The infusion of active GIP (4 pmol/ $\mathrm{kg} / \mathrm{min})$ reduced the blood levels of IL-6 in LPS-induced endotoxemic mice as well [101]. However, opposite results were obtained in a couple of studies (Table 2) [82,100]. Twice daily injections of GIP $(5 \mathrm{nmol} / \mathrm{kg})$ for 1 week augmented the gene expression levels of $\mathrm{Ccl} 2$ and $\mathrm{Il}-6$ in the retroperitoneal or perirenal fat of $d b / d b$ mice, and also increased the $C c l 2$ gene expression levels and macrophage infiltration in the retroperitoneal fat of non-diabetic lean mice [82]. In another study, adipocyte-specific deletion of GIPR gene in HFD-fed mice decreased the lean mass weight and liver steatosis, but not visceral or subcutaneous fat weight, with concomitant reductions in blood levels of IL-6 and adipose tissue gene expression levels of Il-6 and suppressor of cytokine signaling 3, which is a downstream mediator of IL-6 [100]. Taken together, physiological levels of GIP may promote adipose tissue inflammation, whereas GIP at the pharmacological dose could exert anti-inflammatory effects in the adipose tissues.

\subsection{Limitation of Animal Studies}

Male animals were exclusively used in the animal studies (Table 2), possibly due to avoiding potential CV protective effects of estrogen, which needs to be considered in the case of female animals. However, diabetes confers a higher relative risk of CVD mortality among women than among men $[110,111]$. It remains completely unclear whether the CV effects of GIP demonstrated in male animals can be observed in female non-diabetic and diabetic mice. 


\section{Human Studies}

\subsection{Blood Flow and Blood Pressure}

The effects of GIP on blood flow and blood pressure are reported by a couple of studies, in which GIP was intravenously infused at physiological doses that could mimic post-prandial blood levels of GIP (Table 3) [112,113]. GIP infusion, which was started at $10.8 \mathrm{pmol} / \mathrm{kg} / \mathrm{min}$ and gradually decreased to $4.0 \mathrm{pmol} / \mathrm{kg} / \mathrm{min}$ at $240 \mathrm{~min}$, reduced the mean arterial blood pressure by $10-15 \mathrm{mmHg}$, and increased the heart rate by $<8 \mathrm{bpm}$ in individuals with normal glucose tolerance, impaired glucose tolerance, or type 2 diabetes ( $\mathrm{n}=10$ [men, 6; women, 4], 10 [men, 6; women, 4], and 9 [men, 3; women, 6], respectively; no information for ethnicity) [114]. Another study investigated the effects of GIP on blood flow in non-obese young healthy men ( $n=10$, no information for ethnicity) under the pancreatic clamp, which was composed of the co-infusion of somatostatin, insulin, glucagon, and growth hormone at the fixed dose of each [115]. GIP infusion at $1.5 \mathrm{pmol} / \mathrm{kg} / \mathrm{min}$ for $1.5 \mathrm{~h}$ increased the blood flow in the femoral artery, but not those in brachial or carotid artery or flow-mediated brachial artery dilation in the hyperglycemic phase, whereas the same infusion of GIP showed no effect on these parameters in the normoglycemic phase. GIP-induced reductions in systolic blood pressure and increases in arterial blood flow could play a protective role against CVD, whereas GIP-induced increases in heart rate may have harmful effects. Given the fact that CV events were reduced by treatment with GLP-1RAs, which could induce similar changes in systolic blood pressure and heart rate as GIP [29-33], overall effects of GIP may be beneficial against CVD.

Table 3. Cardiovascular effects of GIP in human studies. $\uparrow$, increase; $\downarrow$ decrease.

\begin{tabular}{cc}
\hline Subject & Change \\
\hline & $\downarrow$ Mean arterial blood pressure [114] \\
$\uparrow$ Heart rate [114] \\
Normal glucose tolerance or young healthy & $\uparrow$ Femoral artery blood flow [115] \\
$\uparrow$ Blood levels of CCL2 [78], CCL8 [78], \\
and osteopontin [62] \\
$\uparrow$ Adipose tissue levels of CCL2 [78], CCL8 [78], \\
and IL-6 [78] \\
\hline Impaired glucose tolerance \\
Type 2 diabetes & $\begin{array}{c}\uparrow \text { Heart rate [114] } \\
\text { TMean arterial blood pressure [114] } \\
\uparrow \text { Heart rate [114] }\end{array}$ \\
\hline
\end{tabular}

\subsection{Inflammatory Cytokine and Chemokine}

There are a couple of studies evaluating the effects of GIP on pro-inflammatory cytokines in humans (Table 3) [62,78]. GIP infusion at $2 \mathrm{pmol} / \mathrm{kg} / \mathrm{min}$ for $240 \mathrm{~min}$ increased the blood levels of CCL2 or CCL8 and subcutaneous adipose tissue gene expression levels of CCL2, CCL8, and IL-6 in obese men with normal glucose tolerance ( $n=17$, no information for ethnicity) [78]. In addition, these changes were also observed both under euglycemic- and hyperglycemic-hyperinsulinemic clamps. In another study enrolling healthy subjects ( $n=47$, no information for gender and ethnicity), GIP infusion at $4 \mathrm{pmol} / \mathrm{kg} / \mathrm{min}$ for $105 \mathrm{~min}$ increased the blood levels of osteopontin, which was dependent on GIPR genotypes under the hyperglycemic clamp [62]. These observations are consistent with the in vivo findings that physiological level of GIP is involved in adipose tissue inflammation in animal models [82,100]. However, it remains unclear whether pharmacological concentrations of GIP can induce similar pro-inflammatory changes, or conversely suppress the inflammation because both physiological GIP inhibition and pharmacological GIP administration can similarly induce anti-obesity effects [46-50,52]. In addition, data is still missing to elucidate roles of gender and ethnicity in effects of GIP on inflammation. 


\section{Concerns about GIP Therapy}

\subsection{GIPR Downregulation under Hyperglycemia}

As above-mentioned, insulinotropic effects of GIP has been shown to be impaired in individuals with diabetes, possibly through hyperglycemia-induced downregulation of GIPR expression in pancreatic beta cells [42-44,116-118]. However, influence of hyperglycemia on GIPR expression in vascular cells is controversial $[21,27,62,63]$. Several studies, including ours, have shown that exposure to hyperglycemia decreased the gene or protein levels of GIPR in HUVECs and several types of monocytes/macrophages $[21,27,63]$. We have also found that Gipr gene expression levels are halved in the aortas and pancreases of hyperglycemic $d b / d b$ mice compared with normoglycemic wild-type mice [27]. On the other hand, another report showed that Gipr gene expression levels were not changed in mouse aortic ECs, but upregulated in mouse aortic SMCs under hyperglycemic conditions in vitro [62]. Furthermore, Gipr gene expression levels were upregulated in the carotid arteries of diabetic LDL receptor-knockout mice compared with non-diabetic mice in vivo [62]. Therefore, further studies are needed to clarify whether GIPR expression in vascular cells can be altered in diabetic conditions. However, given the fact that GIP suppressed the atherosclerosis and restenosis in diabetic mice [21,27], beneficial cardiovascular effects of GIP are likely to be preserved, at least partly, in diabetic conditions.

\subsection{GIPR Desensitization under Chronic Stimulation}

GIPR undergoes very rapid and reversible homologous desensitization upon GIP binding, which is considered an important response to regulate the GIP actions in GIPR-expressing cells [119]. Thus, there is a concern that chronic administration of GIP may lead to impaired actions of GIP through GIPR desensitization. An early study showed that the continuous infusion of human GIP to normal rats increased the blood levels of insulin up to $30 \mathrm{~min}$, which was gradually decreased afterward, returning to the baseline levels at $4 \mathrm{~h}$ [120]. Similarly, in cAMP reporter L-cells expressing rat GIP receptor, human GIP at $2 \mathrm{nM}$ increased the cAMP-dependent $\beta$-galactosidase production up to $4 \mathrm{~h}$, which was disappeared at $16 \mathrm{~h}$ after GIP stimulation. In addition, pre-incubation with GIP at $2 \mathrm{nM}$ for $16 \mathrm{~h}$ also diminished the effects of subsequent GIP stimulation on cAMP-dependent $\beta$-galactosidase production. Another study also reported the desensitization of GIPR after GIP stimulation in cultured differentiated mouse 3T3-L1 adipocytes [121]. GIP stimulation at $100 \mathrm{nM}$ for 60 min increased the cAMP levels, which was approximately halved in the second GIP stimulation at $100 \mathrm{nM}$ for 15 minutes in association with decreased numbers of GIPR on the cell surface after the first GIP stimulation.

There are a couple of studies demonstrating that insulinotropic effects of GIP can be preserved after chronic stimulation [122,123]. Degradation resistant GIP analog, N-AcGIP (LysPAL [37]) at $12.5 \mathrm{nmol} / \mathrm{kg} /$ day once daily was injected to diabetic $o b / o b$ mice, but its insulinotropic effects were similarly observed at 14 days after the serial injections [122]. In addition, another study reported that insulinotropic effects of GIP were not impaired by exposure to slightly supra-physiological concentrations of GIP in healthy subjects and age- gender- and weight-matched patients with type 2 diabetes and first-degree relatives of such patients [123]. GIP at $50 \mathrm{pmol} / \mathrm{kg}$ was injected to the subjects before and after continuous GIP infusion at $2 \mathrm{pmol} / \mathrm{kg} / \mathrm{min}$ for $150 \mathrm{~min}$. However, there was no difference between insulinotropic effects of the first and second GIP injections in any of the groups. These findings suggest that GIP-induced cAMP production may be blunted to some extent after chronic GIP stimulation via GIPR desensitization, but it can be still sufficient to stimulate insulin secretion in pancreatic beta cells.

\section{Further Perspective: Potential Effects of GIP as an Enhancer for GLP-1 Actions}

Recent in vitro studies have demonstrated that GIP may enhance GLP-1 actions through binding to GLP-1R/GIPR heterodimer. GIPR and GLP-1 belong to G protein-coupled receptors, which function as not only monomers but also heterodimers or homodimers [124,125]. Several studies reported that GLP-1R/GIPR heterodimer was formed in HEK-293 cells expressing these receptors, and the heterodimer 
resulted in an impaired response to GLP-1 stimulation [126-128]. Interestingly, the heterodimer formation was promoted by GLP-1 stimulation, whereas it was reversed by GIP stimulation [127]. These findings suggest a possibility that GIP can act as an enhancer of GLP-1 actions in cells expressing both GLP-1R and GIPR such as VECs. Although these in vitro findings need to be confirmed by in vivo studies, this effect of GIP may be one of mechanisms, by which the GLP-1R/GIPR dual agonist LY3298176 exerted superior metabolic effects compared with the GLP-1R mono-agonist dulaglutide [54].

\section{Conclusions}

GIP can exhibit both anti-atherogenic and pro-atherogenic properties in vitro: the former is enhancement of NO production and AMPK activation in VECs, inhibition of cell proliferation in VSMCs, and suppression of inflammatory responses in monocytes, macrophages, and adipocytes. The latter is enhancement of ET-1 production in VECs and osteopontin production in VSMCs, and provocation of inflammatory responses in adipocytes (Figure 1). However, overall effects of GIP at pharmacological concentrations are likely to be protective against atherosclerosis both in non-diabetic and diabetic conditions in vivo. Furthermore, recent in vivo studies have demonstrated multiple beneficial effects of GIP on diabetes-related diseases, such as Alzheimer's disease [129-134] and osteoporosis [135-146]. These findings suggest that dual or triple agonists including GIPR, which will be available in the near future [54-56], could be comprehensive treatment for diabetes and its related disorders.

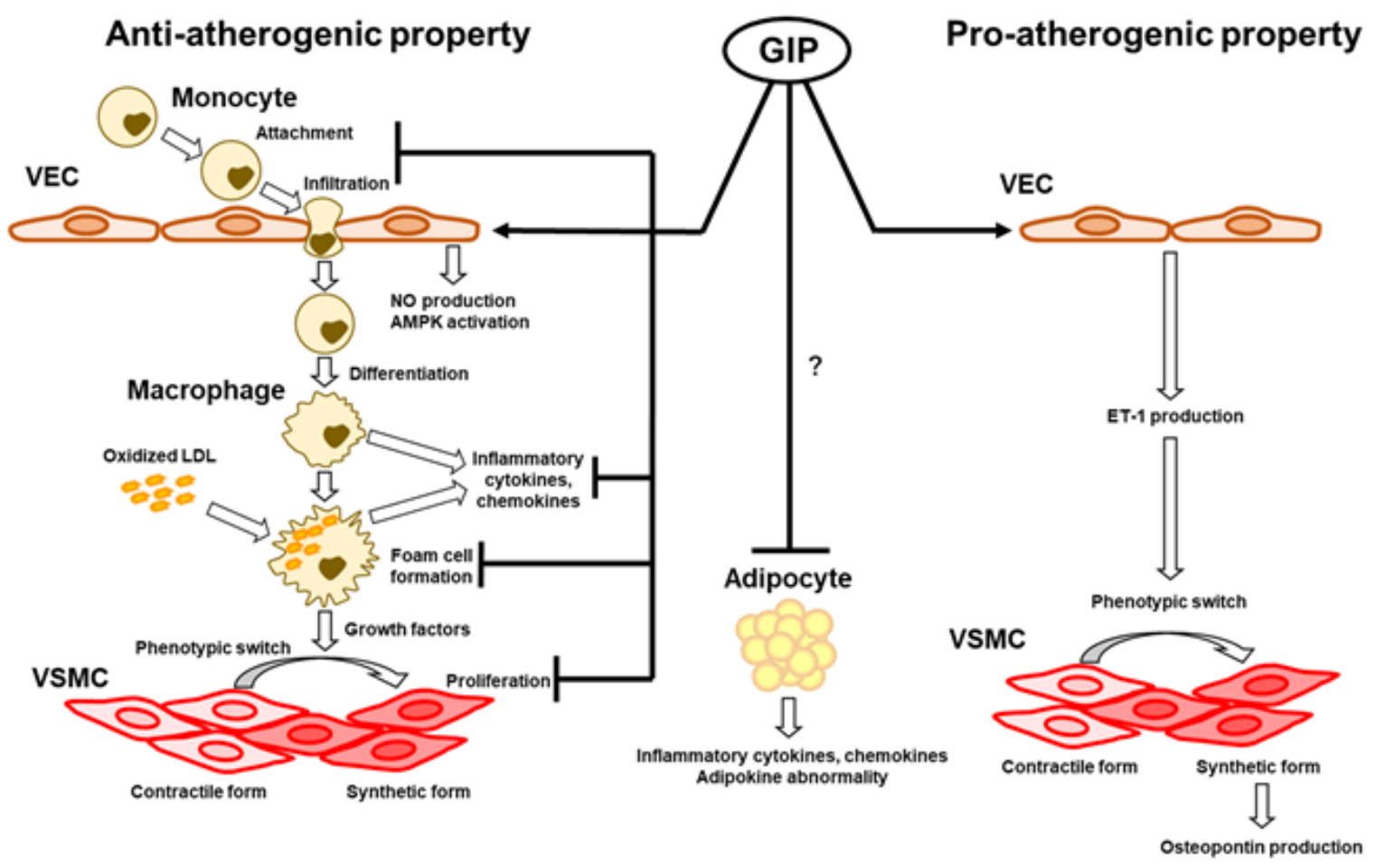

Figure 1. Anti-atherogenic and proatherogenic properties of GIP in vasculatures.

Anti-atherogenic effects of GIP are induced by enhancement of nitric oxide (NO) production and AMP-activated protein kinase (AMPK) activation in vascular endothelial cells (VECs), suppression of cell proliferation in vascular smooth muscle cells (VSMCs), and suppression of inflammatory responses and form cell formation in monocytes/macrophages or adipocytes. Pro-atherogenic effects of GIP are associated with enhancement of endothelin-1 (ET-1) production in VECs, ET-1-mediated osteopontin production in VSMCs, and provocation of inflammatory responses in adipocytes. 
Author Contributions: Y.M. drafted the manuscript. T.M., T.H., and S.-i.Y. revised the manuscript. All authors approved the submitted version of the manuscript, and agreed to be personally accountable for their own contributions and for ensuring that questions related to the accuracy or integrity of any part of the work.

Funding: This research received no external funding. Y.M. have received financial supports from JSPS KAKENHI (Grant Number 16K21370), Suzuken Memorial Foundation, and Taisho Pharmaceutical. T.M. received financial support from Nippon Boehringer Ingelheim Co., Ltd., Bayer Yakuhin Ltd., Sanofi K.K., Astellas Pharma Inc., Daiichi Sankyo Company, Ltd. and MSD K.K.. TH received lecture fees from Astra Zeneca, Daiichi Sankyo Company, Ltd., Eli Lilly Japan, Kowa, Mitsubishi Tanabe Pharma, MSD K.K., Novartis Pharma, Novo Nordisk Pharma, Ono Pharmaceutical, and Takeda. SY received honoraria such as lecture fees from Nippon Boehringer Ingelheim Co., Ltd., Sanofi K.K., Eli Lilly Japan, Ono Pharmaceutical and MSD K.K.

Conflicts of Interest: There is no conflict of interest to be disclosed.

\section{Abbreviations}

\begin{tabular}{ll} 
AGE & Advanced glycation end product \\
AMPK & AMP-activated protein kinase \\
ApoE-/- & Apolipoprotein E knockout \\
CaMKK & Calcium/calmodulin-dependent protein kinase kinase \\
cAMP & Cyclic adenosine monophosphate \\
CCL & Chemokine ligand \\
CREB & cAMP response element-binding protein \\
CVD & Cardiovascular disease \\
DPP & Dipeptidyl peptidase \\
ET & Endothelin \\
GIP & Glucose-dependent insulinotropic polypeptide \\
GIPR & GIP receptor \\
GLP-1 & Glucagon like peptide-1 \\
GLP-1RA & GLP-1 receptor agonist \\
HUV & Human umbilical vein \\
IL & Interleukin \\
LDL & Low density lipoprotein \\
LKB & Liver kinase B \\
LPS & Lipopolysaccharide \\
NO & Nitric oxide \\
NOS & Nitric oxide synthase \\
PAI & Plasminogen activator inhibitor \\
PKA & Protein kinase A \\
PLC & Phospholipase C \\
PTA & Percutaneous transluminal angioplasty \\
SMC & Smooth muscle cell \\
TNF & Tumor necrosis factor \\
VEC & Vascular endothelial cell \\
VSMC & Vascular smooth muscle cell \\
& \\
\hline &
\end{tabular}

\section{References}

1. Seshasai, S.R.K.; Kaptoge, S.; Thompson, A.; Di Angelantonio, E.; Gao, P.; Sarwar, N.; Whincup, P.H.; Mukamal, K.J.; Gillum, R.F.; Holme, I.; et al. Emerging Risk Factors Collaboration. Diabetes mellitus, fasting glucose, and risk of cause-specific death. N. Engl. J. Med. 2011, 364, 829-841.

2. Wang, C.C.L.; Hess, C.N.; Hiatt, W.R.; Goldfine, A.B. Clinical Update: Cardiovascular Disease in Diabetes Mellitus: Atherosclerotic Cardiovascular Disease and Heart Failure in Type 2 Diabetes Mellitus-Mechanisms, Management, and Clinical Considerations. Circulation 2016, 133, 2459-2502. [CrossRef] [PubMed]

3. Nathan, D.M.; Cleary, P.A.; Backlund, J.Y.; Genuth, S.M.; Lachin, J.M.; Orchard, T.J.; Raskin, P.; Zinman, B.; Diabetes Control and Complications Trial/Epidemiology of Diabetes Interventions and Complications (DCCT/EDIC) Study Research Group. Intensive diabetes treatment and cardiovascular disease in patients with type 1 diabetes. N. Engl. J. Med. 2005, 353, 2643-2653. [PubMed] 
4. Action to Control Cardiovascular Risk in Diabetes Study Group; Gerstein, H.C.; Miller, M.E.; Byington, R.P.; Goff, D.C., Jr.; Bigger, J.T.; Buse, J.B.; Cushman, W.C.; Genuth, S.; Ismail-Beigi, F.; et al. Effects of intensive glucose lowering in type 2 diabetes. N. Engl. J. Med. 2008, 358, 2545-2559. [PubMed]

5. ADVANCE Collaborative Group; Patel, A.; MacMahon, S.; Chalmers, J.; Neal, B.; Billot, L.; Woodward, M.; Marre, M.; Cooper, M.; Glasziou, P.; et al. Intensive blood glucose control and vascular outcomes in patients with type 2 diabetes. N. Engl. J. Med. 2008, 358, 2560-2572.

6. Holman, R.R.; Paul, S.K.; Bethel, M.A.; Matthews, D.R.; Neil, H.A. 10-year follow-up of intensive glucose control in type 2 diabetes. N. Engl. J. Med. 2008, 359, 1577-1589. [CrossRef]

7. Duckworth, W.; Abraira, C.; Moritz, T.; Reda, D.; Emanuele, N.; Reaven, P.D.; Zieve, F.J.; Marks, J.; Davis, S.N.; Hayward, R.; et al. Glucose control and vascular complications in veterans with type 2 diabetes. N. Engl. J. Med. 2009, 360, 129-139. [CrossRef]

8. Takeuchi, M.; Yamagishi, S. Possible involvement of advanced glycation end-products (AGEs) in the pathogenesis of Alzheimer's disease. Curr. Pharm. Des. 2008, 14, 973-978. [CrossRef]

9. Yamagishi, S. Role of advanced glycation end products (AGEs) in osteoporosis in diabetes. Curr. Drug Targets 2011, 12, 2096-2102. [CrossRef]

10. Rhodes, E.T.; Prosser, L.A.; Hoerger, T.J.; Lieu, T.; Ludwig, D.S.; Laffel, L.M. Estimated morbidity and mortality in adolescents and young adults diagnosed with Type 2 diabetes mellitus. Diabet. Med. 2012, 29, 453-463. [CrossRef]

11. Seino, Y.; Fukushima, M.; Yabe, D. GIP and GLP-1, the two incretin hormones: Similarities and differences. J. Diabet. Investig. 2010, 1, 8-23. [CrossRef] [PubMed]

12. Campbell, J.E.; Drucker, D.J. Pharmacology, physiology, and mechanisms of incretin hormone action. Cell Metab. 2013, 17, 819-837. [CrossRef] [PubMed]

13. Lovshin, J.A.; Drucker, D.J. Incretin-based therapies for type 2 diabetes mellitus. Nat. Rev. Endocrinol. 2009, 5, $262-269$. [CrossRef] [PubMed]

14. Goto, A.; Arah, O.A.; Goto, M.; Terauchi, Y.; Noda, M. Severe hypoglycaemia and cardiovascular disease: Systematic review and meta-analysis with bias analysis. BMJ 2013, 347, f4533. [CrossRef]

15. International Hypoglycaemia Study Group. Hypoglycaemia, cardiovascular disease, and mortality in diabetes: Epidemiology, pathogenesis, and management. Lancet Diabet. Endocrinol. 2019, 7, 385-396. [CrossRef]

16. Seino, Y.; Yabe, D. Glucose-dependent insulinotropic polypeptide and glucagon-like peptide-1: Incretin actions beyond the pancreas. J. Diabet. Investig. 2013, 4, 108-130. [CrossRef]

17. Ishibashi, Y.; Matsui, T.; Takeuchi, M.; Yamagishi, S. Glucagon-like peptide-1 (GLP-1) inhibits advanced glycation end product (AGE)-induced up-regulation of VCAM-1 mRNA levels in endothelial cells by suppressing AGE receptor (RAGE) expression. Biochem. Biophys. Res. Commun. 2010, 391, 1405-1408. [CrossRef]

18. Matsui, T.; Nishino, Y.; Takeuchi, M.; Yamagishi, S. Vildagliptin blocks vascular injury in thoracic aorta of diabetic rats by suppressing advanced glycation end product-receptor axis. Pharmacol. Res. 2011, 63, 383-388. [CrossRef]

19. Nagashima, M.; Watanabe, T.; Terasaki, M.; Tomoyasu, M.; Nohtomi, K.; Kim-Kaneyama, J.; Miyazaki, A.; Hirano, T. Native incretins prevent the development of atherosclerotic lesions in apolipoprotein E knockout mice. Diabetologia 2011, 54, 2649-2659. [CrossRef]

20. Terasaki, M.; Nagashima, M.; Watanabe, T.; Nohtomi, K.; Mori, Y.; Miyazaki, A.; Hirano, T. Effects of PKF275-055, a dipeptidyl peptidase-4 inhibitor, on the development of atherosclerotic lesions in apolipoprotein E-null mice. Metabolism 2012, 61, 974-977. [CrossRef]

21. Nogi, Y.; Nagashima, M.; Terasaki, M.; Nohtomi, K.; Watanabe, T.; Hirano, T. Glucose-dependent insulinotropic polypeptide prevents the progression of macrophage-driven atherosclerosis in diabetic apolipoprotein E-null mice. PLoS ONE 2012, 7, e35683. [CrossRef] [PubMed]

22. Ishibashi, Y.; Matsui, T.; Maeda, S.; Higashimoto, Y.; Yamagishi, S. Advanced glycation end products evoke endothelial cell damage by stimulating soluble dipeptidyl peptidase-4 production and its interaction with mannose 6-phosphate/insulin-like growth factor II receptor. Cardiovasc. Diabetol. 2013, 12, 125. [CrossRef] [PubMed]

23. Terasaki, M.; Nagashima, M.; Nohtomi, K.; Kohashi, K.; Tomoyasu, M.; Sinmura, K.; Nogi, Y.; Katayama, Y.; Sato, K.; Itoh, F; et al. Preventive effect of dipeptidyl peptidase-4 inhibitor on atherosclerosis is mainly attributable to incretin's actions in nondiabetic and diabetic apolipoprotein E-null mice. PLoS ONE 2013, 8, e70933. [CrossRef] [PubMed] 
24. Tashiro, Y.; Sato, K.; Watanabe, T.; Nohtomi, K.; Terasaki, M.; Nagashima, M.; Hirano, T. a glucagon-like peptide-1 analog liraglutide suppresses macrophage foam cell formation and atherosclerosis. Peptides 2014, 54, 19-26. [CrossRef]

25. Hiromura, M.; Mori, Y.; Kohashi, K.; Terasaki, M.; Shinmura, K.; Negoro, T.; Kawashima, H.; Kogure, M.; Wachi, T.; Watanabe, R.; et al. Suppressive Effects of Glucose-Dependent Insulinotropic Polypeptide on Cardiac Hypertrophy and Fibrosis in Angiotensin II-Infused Mouse Models. Circ. J. 2016, 80, 1988-1997. [CrossRef]

26. Kushima, H.; Mori, Y.; Koshibu, M.; Hiromura, M.; Kohashi, K.; Terasaki, M.; Fukui, T.; Hirano, T. The role of endothelial nitric oxide in the anti-restenotic effects of liraglutide in a mouse model of restenosis. Cardiovasc. Diabetol. 2017, 16, 122. [CrossRef]

27. Mori, Y.; Kushima, H.; Koshibu, M.; Saito, T.; Hiromura, M.; Kohashi, K.; Terasaki, M.; Seino, Y.; Yamada, Y.; Hirano, T. Glucose-Dependent Insulinotropic Polypeptide Suppresses Peripheral Arterial Remodeling in Male Mice. Endocrinology 2018, 159, 2717-2732. [CrossRef]

28. Koshibu, M.; Mori, Y.; Saito, T.; Kushima, H.; Hiromura, M.; Terasaki, M.; Takada, M.; Fukui, T.; Hirano, T. Antiatherogenic effects of liraglutide in hyperglycemic apolipoprotein E-null mice via AMP-activated protein kinase-independent mechanisms. Am. J. Physiol. Endocrinol. Metab. 2019, 316, E895-E907. [CrossRef]

29. Marso, S.P.; Daniels, G.H.; Brown-Frandsen, K.; Kristensen, P.; Mann, J.F.; Nauck, M.A.; Nissen, S.E.; Pocock, S.; Poulter, N.R.; Ravn, L.S.; et al. Liraglutide and Cardiovascular Outcomes in Type 2 Diabetes. N. Engl. J. Med. 2016, 375, 311-322. [CrossRef]

30. Marso, S.P.; Bain, S.C.; Consoli, A.; Eliaschewitz, F.G.; Jódar, E.; Leiter, L.A.; Lingvay, I.; Rosenstock, J.; Seufert, J.; Warren, M.L.; et al. Semaglutide and Cardiovascular Outcomes in Patients with Type 2 Diabetes. N. Engl. J. Med. 2016, 375, 1834-1844. [CrossRef]

31. Hernandez, A.F.; Green, J.B.; Janmohamed, S.; D’Agostino Sr, R.B.; Granger, C.B.; Jones, N.P.; Leiter, L.A.; Rosenberg, A.E.; Sigmon, K.N.; Somerville, M.C.; et al. Albiglutide and cardiovascular outcomes in patients with type 2 diabetes and cardiovascular disease (Harmony Outcomes): a double-blind, randomised placebo-controlled trial. Lancet 2018, 392, 1519-1529. [CrossRef]

32. Gerstein, H.C.; Colhoun, H.M.; Dagenais, G.R.; Diaz, R.; Lakshmanan, M.; Pais, P.; Probstfield, J.; Riesmeyer, J.S.; Riddle, M.C.; Rydén, L.; et al. Dulaglutide and cardiovascular outcomes in type 2 diabetes (REWIND): a double-blind, randomised placebo-controlled trial. Lancet 2019, 394, 121-130. [CrossRef]

33. Husain, M.; Birkenfeld, A.L.; Donsmark, M.; Dungan, K.; Eliaschewitz, F.G.; Franco, D.R.; Jeppesen, O.K.; Lingvay, I.; Mosenzon, O.; Pedersen, S.D.; et al. Oral Semaglutide and Cardiovascular Outcomes in Patients with Type 2 Diabetes. N. Engl. J. Med. 2019, 381, 841-851. [CrossRef] [PubMed]

34. Mita, T.; Katakami, N.; Yoshii, H.; Onuma, T.; Kaneto, H.; Osonoi, T.; Shiraiwa, T.; Kosugi, K.; Umayahara, Y.; Yamamoto, T.; et al. Alogliptin, a Dipeptidyl Peptidase 4 Inhibitor, Prevents the Progression of Carotid Atherosclerosis in Patients With Type 2 Diabetes: The Study of Preventive Effects of Alogliptin on Diabetic Atherosclerosis (SPEAD-A). Diabet. Care 2016, 39, 139-148. [CrossRef] [PubMed]

35. Mita, T.; Katakami, N.; Shiraiwa, T.; Yoshii, H.; Onuma, T.; Kuribayashi, N.; Osonoi, T.; Kaneto, H.; Kosugi, K.; Umayahara, Y.; et al. Sitagliptin Attenuates the Progression of Carotid Intima-Media Thickening in Insulin-Treated Patients With Type 2 Diabetes: The Sitagliptin Preventive Study of Intima-Media Thickness Evaluation (SPIKE): a Randomized Controlled Trial. Diabet. Care 2016, 39, 455-464. [CrossRef] [PubMed]

36. Tahara, N.; Yamagishi, S.I.; Bekki, M.; Kodama, N.; Nakamura, T.; Sugiyama, Y.; Oshige, T.; Kumashiro, Y.; Honda, A.; Tahara, A.; et al. Anagliptin, a Dipeptidyl Peptidase-4 Inhibitor Ameliorates Arterial Stiffness in Association with Reduction of Remnant-Like Particle Cholesterol and Alanine Transaminase Levels in Type 2 Diabetic Patients. Curr. Vasc. Pharmacol. 2016, 14, 552-562. [CrossRef]

37. Scirica, B.M.; Bhatt, D.L.; Braunwald, E.; Steg, P.G.; Davidson, J.; Hirshberg, B.; Ohman, P.; Frederich, R.; Wiviott, S.D.; Hoffman, E.B.; et al. Saxagliptin and cardiovascular outcomes in patients with type 2 diabetes mellitus. N. Engl. J. Med. 2013, 369, 1317-1326. [CrossRef]

38. White, W.B.; Bakris, G.L.; Bergenstal, R.M.; Cannon, C.P.; Cushman, W.C.; Fleck, P.; Heller, S.; Mehta, C.; Nissen, S.E.; Perez, A.; et al. EXamination of cArdiovascular outcoMes with alogliptIN versus standard of carE in patients with type 2 diabetes mellitus and acute coronary syndrome (EXAMINE): a cardiovascular safety study of the dipeptidyl peptidase 4 inhibitor alogliptin in patients with type 2 diabetes with acute coronary syndrome. Am. Heart J. 2011, 162, 620-626. 
39. Green, J.B.; Bethel, M.A.; Armstrong, P.W.; Buse, J.B.; Engel, S.S.; Garg, J.; Josse, R.; Kaufman, K.D.; Koglin, J.; Korn, S.; et al. Effect of Sitagliptin on Cardiovascular Outcomes in Type 2 Diabetes. N. Engl. J. Med. 2015, 373, $232-242$. [CrossRef]

40. Rosenstock, J.; Perkovic, V.; Johansen, O.E.; Cooper, M.E.; Kahn, S.E.; Marx, N.; Alexander, J.H.; Pencina, M.; Toto, R.D.; Wanner, C.; et al. Effect of Linagliptin vs. Placebo on Major Cardiovascular Events in Adults With Type 2 Diabetes and High Cardiovascular and Renal Risk: The CARMELINA Randomized Clinical Trial. JAMA 2019, 321, 69-79. [CrossRef]

41. Rosenstock, J.; Kahn, S.E.; Johansen, O.E.; Zinman, B.; Espeland, M.A.; Woerle, H.J.; Pfarr, E.; Keller, A.; Mattheus, M.; Baanstra, D.; et al. Effect of Linagliptin vs. Glimepiride on Major Adverse Cardiovascular Outcomes in Patients With Type 2 Diabetes: The CAROLINA Randomized Clinical Trial. JAMA 2019, 322, 1155-1166. [CrossRef]

42. Nauck, M.; Heimesaat, M.M.; Orskov, C.; Holst, J.J.; Ebert, R.; Creutzfeldt, W. Preserved incretin activity of glucagon-like peptide 1 [7-36 amide] but not of synthetic human gastric inhibitory polypeptide in patients with type-2 diabetes mellitus. J. Clin. Invest. 1993, 91, 301-307. [CrossRef]

43. Vilsbøll, T.; Krarup, T.; Madsbad, S.; Holst, J.J. Defective amplification of the late phase insulin response to glucose by GIP in obese Type II diabetic patients. Diabetologia 2002, 45, 1111-1119. [PubMed]

44. Vilsbøll, T.; Knop, F.K.; Krarup, T.; Johansen, A.; Madsbad, S.; Larsen, S.; Hansen, T.; Pedersen, O.; Holst, J.J. The pathophysiology of diabetes involves a defective amplification of the late-phase insulin response to glucose by glucose-dependent insulinotropic polypeptide-regardless of etiology and phenotype. J. Clin. Endocrinol. Metab. 2003, 88, 4897-4903. [CrossRef] [PubMed]

45. Hauner, H.; Glatting, G.; Kaminska, D.; Pfeiffer, E.F. Effects of gastric inhibitory polypeptide on glucose and lipid metabolism of isolated rat adipocytes. Ann. Nutr. Metab. 1988, 32, 282-288. [CrossRef] [PubMed]

46. Miyawaki, K.; Yamada, Y.; Ban, N.; Thara, Y.; Tsukiyama, K.; Zhou, H.; Fujimoto, S.; Oku, A.; Tsuda, K.; Toyokuni, S.; et al. Inhibition of gastric inhibitory polypeptide signaling prevents obesity. Nat. Med. 2002, 8, 738-742. [CrossRef]

47. Nasteska, D.; Harada, N.; Suzuki, K.; Yamane, S.; Hamasaki, A.; Joo, E.; Iwasaki, K.; Shibue, K.; Harada, T.; Inagaki, N. Chronic reduction of GIP secretion alleviates obesity and insulin resistance under high-fat diet conditions. Diabetes 2014, 63, 2332-2343. [CrossRef] [PubMed]

48. Nakamura, T.; Tanimoto, H.; Mizuno, Y.; Okamoto, M.; Takeuchi, M.; Tsubamoto, Y.; Noda, H. Gastric inhibitory polypeptide receptor antagonist, SKL-14959, suppressed body weight gain on diet-induced obesity mice. Obes. Sci. Pract. 2018, 4, 194-203. [CrossRef] [PubMed]

49. Szalowska, E.; Meijer, K.; Kloosterhuis, N.; Razaee, F.; Priebe, M.; Vonk, R.J. Sub-chronic administration of stable GIP analog in mice decreases serum LPL activity and body weight. Peptides 2011, 32, 938-945. [CrossRef] [PubMed]

50. Kim, S.J.; Nian, C.; Karunakaran, S.; Clee, S.M.; Isales, C.M.; McIntosh, C.H. GIP-overexpressing mice demonstrate reduced diet-induced obesity and steatosis, and improved glucose homeostasis. PLoS ONE 2012, 7, e40156. [CrossRef]

51. NamKoong, C.; Kim, M.S.; Jang, B.T.; Lee, Y.H.; Cho, Y.M.; Choi, H.J. Central administration of GLP-1 and GIP decreases feeding in mice. Biochem. Biophys. Res. Commun. 2017, 490, 247-252. [CrossRef] [PubMed]

52. Mroz, P.A.; Finan, B.; Gelfanov, V.; Yang, B.; Tschöp, M.H.; DiMarchi, R.D.; Perez-Tilve, D. Optimized GIP analogs promote body weight lowering in mice through GIPR agonism not antagonism. Mol. Metab. 2019, 20, 51-62. [CrossRef] [PubMed]

53. Adriaenssens, A.E.; Biggs, E.K.; Darwish, T.; Tadross, J.; Sukthankar, T.; Girish, M.; Polex-Wolf, J.; Lam, B.Y.; Zvetkova, I.; Pan, W.; et al. Glucose-Dependent Insulinotropic Polypeptide Receptor-Expressing Cells in the Hypothalamus Regulate Food Intake. Cell Metab. 2019, 30, 987-996. [CrossRef] [PubMed]

54. Frias, J.P.; Nauck, M.A.; Van, J.; Kutner, M.E.; Cui, X.; Benson, C.; Urva, S.; Gimeno, R.E.; Milicevic, Z.; Robins, D.; et al. Efficacy and safety of LY3298176, a novel dual GIP and GLP-1 receptor agonist, in patients with type 2 diabetes: a randomised, placebo-controlled and active comparator-controlled phase 2 trial. Lancet 2018, 392, 2180-2193. [CrossRef]

55. Frias, J.P.; Bastyr, E.J., 3rd; Vignati, L.; Tschöp, M.H.; Schmitt, C.; Owen, K.; Christensen, R.H.; DiMarchi, R.D. The Sustained Effects of a Dual GIP/GLP-1 Receptor Agonist, NNC0090-2746, in Patients with Type 2 Diabetes. Cell Metab. 2017, 26, 343-352. [CrossRef] [PubMed]

56. Usui, R.; Yabe, D.; Seino, Y. Twincretin as a potential therapeutic for the management of type 2 diabetes with obesity. J. Diabet. Investig. 2019, 10, 902-905. [CrossRef] 
57. Farah, C.; Michel, L.Y.M.; Balligand, J.L. Nitric oxide signalling in cardiovascular health and disease. Nat. Rev. Cardiol. 2018, 15, 292-316. [CrossRef]

58. Choy, J.C.; Granville, D.J.; Hunt, D.W.; McManus, B.M. Endothelial apoptosis: Biochemical characteristics and potential implications for atherosclerosis. J. Mol. Cell Cardiol. 2001, 33, 1673-1690. [CrossRef]

59. Usdin, T.B.; Mezey, E.; Button, D.C.; Brownstein, M.J.; Bonner, T.I. Gastric inhibitory polypeptide receptor, a member of the secretin-vasoactive intestinal peptide receptor family, is widely distributed in peripheral organs and the brain. Endocrinology 1993, 133, 2861-2870. [CrossRef]

60. Ding, K.H.; Zhong, Q.; Isales, C.M. Glucose-dependent insulinotropic peptide stimulates thymidine incorporation in endothelial cells: Role of endothelin-1. Am. J. Physiol. Endocrinol. Metab. 2003, 285, E390-E396. [CrossRef]

61. Ojima, A.; Matsui, T.; Maeda, S.; Takeuchi, M.; Yamagishi, S. Glucose-dependent insulinotropic polypeptide (GIP) inhibits signaling pathways of advanced glycation end products (AGEs) in endothelial cells via its antioxidative properties. Horm. Metab. Res. 2012, 44, 501-505. [CrossRef] [PubMed]

62. Berglund, L.M.; Lyssenko, V.; Ladenvall, C.; Kotova, O.; Edsfeldt, A.; Pilgaard, K.; Alkayyali, S.; Brøns, C.; Forsblom, C.; Jonsson, A.; et al. Glucose-Dependent Insulinotropic Polypeptide Stimulates Osteopontin Expression in the Vasculature via Endothelin-1 and CREB. Diabetes 2016, 65, 239-254. [CrossRef] [PubMed]

63. Lim, D.M.; Park, K.Y.; Hwang, W.M.; Kim, J.Y.; Kim, B.J. Difference in protective effects of GIP and GLP-1 on endothelial cells according to cyclic adenosine monophosphate response. Exp. Ther. Med. 2017, 13, 2558-2564. [CrossRef] [PubMed]

64. Ding, K.H.; Zhong, Q.; Xu, J.; Isales, C.M. Glucose-dependent insulinotropic peptide: Differential effects on hepatic artery vs. portal vein endothelial cells. Am. J. Physiol. Endocrinol. Metab. 2004, 286, E773-E779. [CrossRef]

65. Kogire, M.; Inoue, K.; Sumi, S.; Doi, R.; Yun, M.; Kaji, H.; Tobe, T. Effects of gastric inhibitory polypeptide and glucagon on portal venous and hepatic arterial flow in conscious dogs. Dig. Dis Sci. 1992, 37, 1666-1670. [CrossRef]

66. Zhong, Q.; Bollag, R.J.; Dransfield, D.T.; Gasalla-Herraiz, J.; Ding, K.H.; Min, L.; Isales, C.M. Glucose-dependent insulinotropic peptide signaling pathways in endothelial cells. Peptides 2000, 21, 1427-1432. [CrossRef]

67. Harada, N.; Yamada, Y.; Tsukiyama, K.; Yamada, C.; Nakamura, Y.; Mukai, E.; Hamasaki, A.; Liu, X.; Toyoda, K.; Seino, Y.; et al. a novel GIP receptor splice variant influences GIP sensitivity of pancreatic beta-cells in obese mice. Am. J. Physiol. Endocrinol. Metab. 2008, 294, E61-E68. [CrossRef]

68. Ahlqvist, E.; Osmark, P.; Kuulasmaa, T.; Pilgaard, K.; Omar, B.; Brøns, C.; Kotova, O.; Zetterqvist, A.V.; Stancáková, A.; Jonsson, A.; et al. Link between GIP and osteopontin in adipose tissue and insulin resistance. Diabetes 2013, 62, 2088-2094. [CrossRef]

69. Yamagishi, S.; Imaizumi, T. Diabetic vascular complications: Pathophysiology, biochemical basis and potential therapeutic strategy. Curr. Pharm Des. 2005, 11, 2279-2299. [CrossRef]

70. Yamagishi, S.; Nakamura, K.; Matsui, T. Role of oxidative stress in the development of vascular injury and its therapeutic intervention by nifedipine. Curr. Med. Chem. 2008, 15, 172-177. [CrossRef]

71. Carling, D.; Sanders, M.J.; Woods, A. The regulation of AMP-activated protein kinase by upstream kinases. Int. J. Obes. 2008, 32 (Suppl. 4), S55-S59. [CrossRef] [PubMed]

72. Ewart, M.A.; Kennedy, S. AMPK and vasculoprotection. Pharmacol. Ther. 2011, 131, 242-253. [CrossRef] [PubMed]

73. Gao, F.; Chen, J.; Zhu, H. a potential strategy for treating atherosclerosis: Improving endothelial function via AMP-activated protein kinase. Sci. China Life Sci. 2018, 61, 1024-1029. [CrossRef]

74. Dashwood, M.R.; Tsui, J.C. Endothelin-1 and atherosclerosis: Potential complications associated with endothelin-receptor blockade. Atherosclerosis 2002, 160, 297-304. [CrossRef]

75. Wolak, T. Osteopontin-A multi-modal marker and mediator in atherosclerotic vascular disease. Atherosclerosis 2014, 236, 327-337. [CrossRef] [PubMed]

76. Suzuki, Y.; Nakamura, N.; Miyabe, M.; Nishikawa, T.; Miyajima, S.; Adachi, K.; Mizutani, M.; Kikuchi, T.; Miyazawa, K.; Goto, S.; et al. Anti-inflammatory role of glucose-dependent insulinotropic polypeptide in periodontitis. J. Diabet. Investig. 2016, 7, 497-505. [CrossRef] [PubMed]

77. Kahles, F.; Liberman, A.; Halim, C.; Rau, M.; Möllmann, J.; Mertens, R.W.; Rückbeil, M.; Diepolder, I.; Walla, B.; Diebold, S.; et al. The incretin hormone GIP is upregulated in patients with atherosclerosis and stabilizes plaques in ApoE(-/-) mice by blocking monocyte/macrophage activation. Mol. Metab. 2018, 14, 150-157. [CrossRef] 
78. Gögebakan, Ö.; Osterhoff, M.A.; Schüler, R.; Pivovarova, O.; Kruse, M.; Seltmann, A.C.; Mosig, A.S.; Rudovich, N.; Nauck, M.; Pfeiffer, A.F. GIP increases adipose tissue expression and blood levels of MCP-1 in humans and links high energy diets to inflammation: a randomised trial. Diabetologia 2015, 58, 1759-1768. [CrossRef]

79. Ben-Shlomo, S.; Zvibel, I.; Varol, C.; Spektor, L.; Shlomai, A.; Santo, E.M.; Halpern, Z.; Oren, R.; Fishman, S. Role of glucose-dependent insulinotropic polypeptide in adipose tissue inflammation of dipeptidylpeptidase 4-deficient rats. Obesity 2013, 21, 2331-2341. [CrossRef]

80. Varol, C.; Zvibel, I.; Spektor, L.; Mantelmacher, F.D.; Vugman, M.; Thurm, T.; Khatib, M.; Elmaliah, E.; Halpern, Z.; Fishman, S. Long-acting glucose-dependent insulinotropic polypeptide ameliorates obesity-induced adipose tissue inflammation. J. Immunol. 2014, 193, 4002-4009. [CrossRef]

81. Timper, K.; Grisouard, J.; Sauter, N.S.; Herzog-Radimerski, T.; Dembinski, K.; Peterli, R.; Frey, D.M.; Zulewski, H.; Keller, U.; Müller, B.; et al. Glucose-dependent insulinotropic polypeptide induces cytokine expression, lipolysis, and insulin resistance in human adipocytes. Am. J. Physiol. Endocrinol. Metab. 2013, 304, E1-E13. [CrossRef] [PubMed]

82. Chen, S.; Okahara, F.; Osaki, N.; Shimotoyodome, A. Increased GIP signaling induces adipose inflammation via a HIF-1 $\alpha$-dependent pathway and impairs insulin sensitivity in mice. Am. J. Physiol. Endocrinol. Metab. 2015, 308, E414-E425. [CrossRef] [PubMed]

83. Omar, B.; Banke, E.; Guirguis, E.; Åkesson, L.; Manganiello, V.; Lyssenko, V.; Groop, L.; Gomez, M.F.; Degerman, E. Regulation of the pro-inflammatory cytokine osteopontin by GIP in adipocytes-a role for the transcription factor NFAT and phosphodiesterase 3B. Biochem. Biophys. Res. Commun. 2012, 425, 812-817. [CrossRef] [PubMed]

84. Nie, Y.; Ma, R.C.; Chan, J.C.; Xu, H.; Xu, G. Glucose-dependent insulinotropic peptide impairs insulin signaling via inducing adipocyte inflammation in glucose-dependent insulinotropic peptide receptor-overexpressing adipocytes. FASEB J. 2012, 26, 2383-2393. [CrossRef] [PubMed]

85. Lamon, B.D.; Hajjar, D.P. Inflammation at the molecular interface of atherogenesis: An anthropological journey. Am. J. Pathol. 2008, 173, 1253-1264. [CrossRef]

86. Libby, P.; Ridker, P.M.; Hansson, G.K. Leducq Transatlantic Network on Atherothrombosis. Inflammation in atherosclerosis: From pathophysiology to practice. J. Am. Coll. Cardiol. 2009, 54, 2129-2138. [CrossRef]

87. Rizvi, A.A. Cytokine biomarkers, endothelial inflammation, and atherosclerosis in the metabolic syndrome: Emerging concepts. Am. J. Med. Sci. 2009, 55, 659-665. [CrossRef]

88. Tahara, N.; Yamagishi, S.; Takeuchi, M.; Honda, A.; Tahara, A.; Nitta, Y.; Kodama, N.; Mizoguchi, M.; Kaida, H.; Ishibashi, M.; et al. Positive association between serum level of glyceraldehyde-derived advanced glycation end products and vascular inflammation evaluated by [(18)F] fluorodeoxyglucose positron emission tomography. Diabet. Care 2012, 35, 2618-2625. [CrossRef]

89. Tahara, N.; Tahara, A.; Honda, A.; Nitta, Y.; Kodama, N.; Yamagishi, S.; Imaizumi, T. Molecular imaging of vascular inflammation. Curr. Pharm Des. 2014, 20, 2439-2447. [CrossRef]

90. Chinetti-Gbaguidi, G.; Colin, S.; Staels, B. Macrophage subsets in atherosclerosis. Nat. Rev. Cardiol. 2015, $12,10-17$. [CrossRef]

91. Chistiakov, D.A.; Bobryshev, Y.V.; Orekhov, A.N. Macrophage-mediated cholesterol handling in atherosclerosis. J. Cell Mol. Med. 2016, 20, 17-28. [CrossRef]

92. van Dam, A.D.; Boon, M.R.; Berbée, J.F.P.; Rensen, P.C.N.; van Harmelen, V. Targeting white, brown and perivascular adipose tissue in atherosclerosis development. Eur. J. Pharmacol. 2017, 816, 82-92. [CrossRef] [PubMed]

93. Yip, R.G.; Boylan, M.O.; Kieffer, T.J.; Wolfe, M.M. Functional GIP receptors are present on adipocytes. Endocrinology 1998, 139, 4004-4007. [CrossRef] [PubMed]

94. Weaver, R.E.; Donnelly, D.; Wabitsch, M.; Grant, P.J.; Balmforth, A.J. Functional expression of glucose-dependent insulinotropic polypeptide receptors is coupled to differentiation in a human adipocyte model. Int. J. Obes. 2008, 32, 1705-1711. [CrossRef] [PubMed]

95. Getz, G.S.; Reardon, C.A. Animal models of atherosclerosis. Arterioscler. Thromb. Vasc. Biol. 2012, 32, 1104-1115. [CrossRef]

96. Buccheri, D.; Piraino, D.; Andolina, G.; Cortese, B. Understanding and managing in-stent restenosis: a review of clinical data, from pathogenesis to treatment. J. Thorac. Dis. 2016, 8, E1150-E1162. [CrossRef] 
97. Zhao, L.P.; Xu, W.T.; Wang, L.; Li, H.; Shao, C.L.; Gu, H.B.; Chan, S.P.; Xu, H.F.; Yang, X.J. Influence of insulin resistance on in-stent restenosis in patients undergoing coronary drug-eluting stent implantation after long-term angiographic follow-up. Coron. Artery Dis. 2015, 26, 5-10. [CrossRef]

98. Chaabane, C.; Otsuka, F.; Virmani, R.; Bochaton-Piallat, M.L. Biological responses in stented arteries. Cardiovasc. Res. 2013, 99, 353-363. [CrossRef]

99. Ussher, J.R.; Campbell, J.E.; Mulvihill, E.E.; Baggio, L.L.; Bates, H.E.; McLean, B.A.; Gopal, K.; Capozzi, M.; Yusta, B.; Cao, X.; et al. Inactivation of the Glucose-Dependent Insulinotropic Polypeptide Receptor Improves Outcomes following Experimental Myocardial Infarction. Cell Metab. 2018, 27, 450-460. [CrossRef]

100. Joo, E.; Harada, N.; Yamane, S.; Fukushima, T.; Taura, D.; Iwasaki, K.; Sankoda, A.; Shibue, K.; Harada, T.; Suzuki, K.; et al. Inhibition of Gastric Inhibitory Polypeptide Receptor Signaling in Adipose Tissue Reduces Insulin Resistance and Hepatic Steatosis in High-Fat Diet-Fed Mice. Diabetes 2017, 66, 868-879. [CrossRef]

101. Shah, F.A.; Singamsetty, S.; Guo, L.; Chuan, B.W.; McDonald, S.; Cooper, B.A.; O’Donnell, B.J.; Stefanovski, D.; Wice, B.; Zhang, Y.; et al. Stimulation of the endogenous incretin glucose-dependent insulinotropic peptide by enteral dextrose improves glucose homeostasis and inflammation in murine endotoxemia. Transl. Res. 2018, 193, 1-12. [CrossRef]

102. White, W.B.; Kupfer, S.; Zannad, F.; Mehta, C.R.; Wilson, C.A.; Lei, L.; Bakris, G.L.; Nissen, S.E.; Cushman, W.C.; Heller, S.R.; et al. Cardiovascular Mortality in Patients With Type 2 Diabetes and Recent Acute Coronary Syndromes From the EXAMINE Trial. Diabet. Care 2016, 39, 1267-1273. [CrossRef]

103. Rørth, R.; Jhund, P.S.; Mogensen, U.M.; Kristensen, S.L.; Petrie, M.C.; Køber, L.; McMurray, J.J.V. Risk of Incident Heart Failure in Patients With Diabetes and Asymptomatic Left Ventricular Systolic Dysfunction. Diabet. Care 2018, 41, 1285-1291. [CrossRef] [PubMed]

104. Jia, G.; Hill, M.A.; Sowers, J.R. Diabetic Cardiomyopathy: An Update of Mechanisms Contributing to This Clinical Entity. Circ. Res. 2018, 122, 624-638. [CrossRef] [PubMed]

105. Maack, C.; Lehrke, M.; Backs, J.; Heinzel, F.R.; Hulot, J.S.; Marx, N.; Paulus, W.J.; Rossignol, P.; Taegtmeyer, H.; Bauersachs, J.; et al. Heart failure and diabetes: Metabolic alterations and therapeutic interventions: a state-of-the-art review from the Translational Research Committee of the Heart Failure Association-European Society of Cardiology. Eur. Heart J. 2018, 39, 4243-4254. [CrossRef] [PubMed]

106. Kenny, H.C.; Abel, E.D. Heart Failure in Type 2 Diabetes Mellitus. Circ. Res. 2019, 124, 121-141. [CrossRef]

107. Lee, T.M.; Chen, W.T.; Chang, N.C. Sitagliptin decreases ventricular arrhythmias by attenuated glucose-dependent insulinotropic polypeptide (GIP)-dependent resistin signalling in infarcted rats. Biosci. Rep. 2016, 36, e00307. [CrossRef]

108. Kim, M.; Oh, J.K.; Sakata, S.; Liang, I.; Park, W.; Hajjar, R.J.; Lebeche, D. Role of resistin in cardiac contractility and hypertrophy. J. Mol. Cell Cardiol. 2008, 45, 270-280. [CrossRef]

109. Chemaly, E.R.; Hadri, L.; Zhang, S.; Kim, M.; Kohlbrenner, E.; Sheng, J.; Liang, L.; Chen, J.; K-Raman, P.; Hajjar, R.J.; et al. Long-term in vivo resistin overexpression induces myocardial dysfunction and remodeling in rats. J. Mol. Cell Cardiol. 2011, 51, 144-155. [CrossRef]

110. de Ritter, R.; de Jong, M.; Vos, R.C.; van der Kallen, C.J.H.; Sep, S.J.S.; Woodward, M.; Stehouwer, C.D.A.; Bots, M.L.; Peters, S.A.E. Sex differences in the risk of vascular disease associated with diabetes. Biol. Sex Differ. 2020, 11, 1. [CrossRef]

111. Prospective Studies Collaboration and Asia Pacific Cohort Studies Collaboration. Sex-specific relevance of diabetes to occlusive vascular and other mortality: a collaborative meta-analysis of individual data from 980 793 adults from 68 prospective studies. Lancet Diabet. Endocrinol. 2018, 6, 538-546. [CrossRef]

112. Vollmer, K.; Holst, J.J.; Baller, B.; Ellrichmann, M.; Nauck, M.A.; Schmidt, W.E.; Meier, J.J. Predictors of incretin concentrations in subjects with normal, impaired, and diabetic glucose tolerance. Diabetes 2008, 57, 678-687. [CrossRef] [PubMed]

113. Lee, S.; Yabe, D.; Nohtomi, K.; Takada, M.; Morita, R.; Seino, Y.; Hirano, T. Intact glucagon-like peptide-1 levels are not decreased in Japanese patients with type 2 diabetes. Endocr. J. 2010, 57, 119-126. [CrossRef] [PubMed]

114. Wice, B.M.; Reeds, D.N.; Tran, H.D.; Crimmins, D.L.; Patterson, B.W.; Dunai, J.; Wallendorf, M.J.; Ladenson, J.H.; Villareal, D.T.; Polonsky, K.S. Xenin-25 amplifies GIP-mediated insulin secretion in humans with normal and impaired glucose tolerance but not type 2 diabetes. Diabetes 2012, 61, 1793-1800. [CrossRef]

115. Karstoft, K.; Mortensen, S.P.; Knudsen, S.H.; Solomon, T.P. Direct effect of incretin hormones on glucose and glycerol metabolism and hemodynamics. Am. J. Physiol. Endocrinol. Metab. 2015, 308, E426-E433. [CrossRef] 
116. Højberg, P.V.; Vilsbøll, T.; Rabøl, R.; Knop, F.K.; Bache, M.; Krarup, T.; Holst, J.J.; Madsbad, S. Four weeks of near-normalisation of blood glucose improves the insulin response to glucagon-like peptide-1 and glucose-dependent insulinotropic polypeptide in patients with type 2 diabetes. Diabetologia 2009, 52, $199-207$. [CrossRef]

117. Xu, G.; Kaneto, H.; Laybutt, D.R.; Duvivier-Kali, V.F.; Trivedi, N.; Suzuma, K.; King, G.L.; Weir, G.C.; Bonner-Weir, S. Downregulation of GLP-1 and GIP receptor expression by hyperglycemia: Possible contribution to impaired incretin effects in diabetes. Diabetes 2007, 56, 1551-1558. [CrossRef]

118. Lynn, F.C.; Pamir, N.; Ng, E.H.; McIntosh, C.H.; Kieffer, T.J.; Pederson, R.A. Defective glucose-dependent insulinotropic polypeptide receptor expression in diabetic fatty Zucker rats. Diabetes 2001, 50, 1004-1011. [CrossRef]

119. Ismail, S.; Dubois-Vedrenne, I.; Laval, M.; Tikhonova, I.G.; D'Angelo, R.; Sanchez, C.; Clerc, P.; Gherardi, M.J.; Gigoux, V.; Magnan, R.; et al. Internalization and desensitization of the human glucose-dependent-insulinotropic receptor is affected by $\mathrm{N}$-terminal acetylation of the agonist. Mol. Cell Endocrinol. 2015, 414, 202-215. [CrossRef]

120. Tseng, C.C.; Boylan, M.O.; Jarboe, L.A.; Usdin, T.B.; Wolfe, M.M. Chronic desensitization of the glucose-dependent insulinotropic polypeptide receptor in diabetic rats. Am. J. Physiol. 1996, 270, E661-E666. [CrossRef]

121. Mohammad, S.; Patel, R.T.; Bruno, J.; Panhwar, M.S.; Wen, J.; McGraw, T.E. a naturally occurring GIP receptor variant undergoes enhanced agonist-induced desensitization, which impairs GIP control of adipose insulin sensitivity. Mol. Cell Biol. 2014, 34, 3618-3629. [CrossRef]

122. Irwin, N.; Green, B.D.; Mooney, M.H.; Greer, B.; Harriott, P.; Bailey, C.J.; Gault, V.A.; O’Harte, F.P.; Flatt, P.R. a novel, long-acting agonist of glucose-dependent insulinotropic polypeptide suitable for once-daily administration in type 2 diabetes. J. Pharmacol. Exp. Ther. 2005, 314, 1187-1194. [CrossRef]

123. Nauck, M.A.; Holle, H.; Kahle, M.; Tytko, A.; Deacon, C.F.; Holst, J.J.; Meier, J.J. No evidence of tachyphylaxis for insulinotropic actions of Glucose-Dependent Insulinotropic Polypeptide (GIP) in subjects with type 2 diabetes, their first-degree relatives, or in healthy subjects. Peptides 2019. [CrossRef]

124. Gurevich, V.V.; Gurevich, E.V. GPCR monomers and oligomers: It takes all kinds. Trends Neurosci. 2008, $31,74-81$. [CrossRef]

125. Harikumar, K.G.; Wootten, D.; Pinon, D.I.; Koole, C.; Ball, A.M.; Furness, S.G.; Graham, B.; Dong, M.; Christopoulos, A.; Miller, L.J; et al. Glucagon-like peptide-1 receptor dimerization differentially regulates agonist signaling but does not affect small molecule allostery. Proc. Natl. Acad. Sci. USA 2012, 109, 18607-18612. [CrossRef]

126. Whitaker, G.M.; Lynn, F.C.; McIntosh, C.H.; Accili, E.A. Regulation of GIP and GLP1 receptor cell surface expression by $\mathrm{N}$-glycosylation and receptor heteromerization. PLoS ONE 2012, 7, e32675. [CrossRef]

127. Schelshorn, D.; Joly, F.; Mutel, S.; Hampe, C.; Breton, B.; Mutel, V.; Lütjens, R. Lateral allosterism in the glucagon receptor family: Glucagon-like peptide 1 induces $\mathrm{G}$-protein-coupled receptor heteromer formation. Mol. Pharmacol. 2012, 81, 309-318. [CrossRef] [PubMed]

128. Roed, S.N.; Nøhr, A.C.; Wismann, P.; Iversen, H.; Bräuner-Osborne, H.; Knudsen, S.M.; Waldhoer, M. Functional consequences of glucagon-like peptide-1 receptor cross-talk and trafficking. J. Biol. Chem. 2015, 290, 1233-1243. [CrossRef] [PubMed]

129. Gault, V.A.; Hölscher, C. Protease-resistant glucose-dependent insulinotropic polypeptide agonists facilitate hippocampal LTP and reverse the impairment of LTP induced by beta-amyloid. J. Neurophysiol. 2008, 99, 1590-1595. [CrossRef]

130. Faivre, E.; Gault, V.A.; Thorens, B.; Hölscher, C. Glucose-dependent insulinotropic polypeptide receptor knockout mice are impaired in learning, synaptic plasticity, and neurogenesis. J. Neurophysiol. 2011, 105, 1574-1580. [CrossRef] [PubMed]

131. Faivre, E.; Hölscher, C. D-Ala2GIP facilitated synaptic plasticity and reduces plaque load in aged wild type mice and in an Alzheimer's disease mouse model. J. Alzheimers Dis. 2013, 35, 267-283. [CrossRef]

132. Duffy, A.M.; Hölscher, C. The incretin analogue D-Ala2GIP reduces plaque load, astrogliosis and oxidative stress in an APP/PS1 mouse model of Alzheimer's disease. Neuroscience 2013, 228, 294-300. [CrossRef]

133. Faivre, E.; Hölscher, C. Neuroprotective effects of D-Ala(2)GIP on Alzheimer's disease biomarkers in an APP/PS1 mouse model. Alzheimers Res. Ther. 2013, 5, 20. [CrossRef] 
134. Lennox, R.; Moffett, R.C.; Porter, D.W.; Irwin, N.; Gault, V.A.; Flatt, P.R. Effects of glucose-dependent insulinotropic polypeptide receptor knockout and a high-fat diet on cognitive function and hippocampal gene expression in mice. Mol. Med. Rep. 2015, 12, 1544-1548. [CrossRef]

135. Bollag, R.J.; Zhong, Q.; Ding, K.H.; Phillips, P.; Zhong, L.; Qin, F.; Cranford, J.; Mulloy, A.L.; Cameron, R.; Isales, C.M. Glucose-dependent insulinotropic peptide is an integrative hormone with osteotropic effects. Mol. Cell Endocrinol. 2001, 177, 35-41. [CrossRef]

136. Xie, D.; Cheng, H.; Hamrick, M.; Zhong, Q.; Ding, K.H.; Correa, D.; Williams, S.; Mulloy, A.; Bollag, W.; Bollag, R.J.; et al. Glucose-dependent insulinotropic polypeptide receptor knockout mice have altered bone turnover. Bone 2005, 37, 759-769. [CrossRef]

137. Tsukiyama, K.; Yamada, Y.; Yamada, C.; Harada, N.; Kawasaki, Y.; Ogura, M.; Bessho, K.; Li, M.; Amizuka, N.; Sato, M.; et al. Gastric inhibitory polypeptide as an endogenous factor promoting new bone formation after food ingestion. Mol. Endocrinol. 2006, 20, 1644-1651. [CrossRef]

138. Xie, D.; Zhong, Q.; Ding, K.H.; Cheng, H.; Williams, S.; Correa, D.; Bollag, W.B.; Bollag, R.J.; Insogna, K.; Troiano, N.; et al. Glucose-dependent insulinotropic peptide-overexpressing transgenic mice have increased bone mass. Bone 2007, 40, 1352-1360. [CrossRef]

139. Ding, K.H.; Shi, X.M.; Zhong, Q.; Kang, B.; Xie, D.; Bollag, W.B.; Bollag, R.J.; Hill, W.; Washington, W.; Mi, Q.S.; et al. Impact of glucose-dependent insulinotropic peptide on age-induced bone loss. J. Bone Miner. Res. 2008, 23, 536-543. [CrossRef]

140. Nissen, A.; Christensen, M.; Knop, F.K.; Vilsbøll, T.; Holst, J.J.; Hartmann, B. Glucose-dependent insulinotropic polypeptide inhibits bone resorption in humans. J. Clin. Endocrinol. Metab. 2014, 99, E2325-E2329. [CrossRef]

141. Mansur, S.A.; Mieczkowska, A.; Bouvard, B.; Flatt, P.R.; Chappard, D.; Irwin, N.; Mabilleau, G. Stable Incretin Mimetics Counter Rapid Deterioration of Bone Quality in Type 1 Diabetes Mellitus. J. Cell Physiol. 2015, 230, 3009-3018. [CrossRef] [PubMed]

142. Christensen, M.B.; Lund, A.; Calanna, S.; Jørgensen, N.R.; Holst, J.J.; Vilsbøll, T.; Knop, F.K. Glucose-Dependent Insulinotropic Polypeptide (GIP) Inhibits Bone Resorption Independently of Insulin and Glycemia. J. Clin. Endocrinol. Metab. 2018, 103, 288-294. [CrossRef]

143. Shimazu-Kuwahara, S.; Kanemaru, Y.; Harada, N.; Ikeguchi, E.; Ueda, Y.; Yamane, S.; Murata, Y.; Yasoda, A.; Kieffer, T.J.; Inagaki, N. Glucose-dependent insulinotropic polypeptide deficiency reduced fat accumulation and insulin resistance, but deteriorated bone loss in ovariectomized mice. J. Diabet. Investig. 2019, 10, 909-914. [CrossRef]

144. Bergmann, N.C.; Lund, A.; Gasbjerg, L.S.; Jørgensen, N.R.; Jessen, L.; Hartmann, B.; Holst, J.J.; Christensen, M.B.; Vilsbøll, T.; Knop, F.K. Separate and Combined Effects of GIP and GLP-1 Infusions on Bone Metabolism in Overweight Men Without Diabetes. J. Clin. Endocrinol. Metab. 2019, 104, 2953-2960. [CrossRef]

145. Skov-Jeppesen, K.; Svane, M.S.; Martinussen, C.; Gabe, M.B.N.; Gasbjerg, L.S.; Veedfald, S.; Bojsen-Møller, K.N.; Madsbad, S.; Holst, J.J.; Rosenkilde, M.M.; et al. GLP-2 and GIP exert separate effects on bone turnover: a randomized, placebo-controlled, crossover study in healthy young men. Bone 2019, 125, 178-185. [CrossRef]

146. Vyavahare, S.S.; Mieczkowska, A.; Flatt, P.R.; Chappard, D.; Irwin, N.; Mabilleau, G. GIP analogues augment bone strength by modulating bone composition in diet-induced obesity in mice. Peptides 2019. [CrossRef]

(C) 2020 by the authors. Licensee MDPI, Basel, Switzerland. This article is an open access article distributed under the terms and conditions of the Creative Commons Attribution (CC BY) license (http://creativecommons.org/licenses/by/4.0/). 